\title{
THE EFFECT OF THE DIET ON INCIDENCE OF FOOT- PAD LESIONS AND PRODUCTIVITY OF BROILERS
}

\author{
Z. Š́krbić ${ }^{1}$, Z. Pavlovski ${ }^{1}$, M. Lukićc ${ }^{1}$, V. Petričević ${ }^{1}$, B. Miljković ${ }^{2}$, G. \\ Marinkov ${ }^{1}$ \\ ${ }^{1}$ Institute for Animal Husbandry, Autoput 16, P.Box 23, 11080 Belgrade, Republic of Serbia \\ ${ }^{2}$ Scientific Institute of veterinary medicine of Serbia, Vojvode Toze 14, 11000 Belgrade, Republic of \\ Serbia \\ Corresponding author: zdskrbic@gmail.com \\ Original scientific paper
}

Abstract: Nutrition factors are considered to be very important for incidence of foot-pad dermatitis through the effect on the quality of litter. Objective of this study was to investigate the effect of the use of two feeding programs for broilers available on the market and declared in the nutritional/economical sense as standard and economical, on quality of litter, incidence of leg dermatitis (foot-pad and hock burns) and production performance. Trial was carried out on 500 one day old chickens of Hubbard genotype, in two treatments and five replicates. Chopped straw was used as litter. During the trial, the mortality and food consumption were monitored, and at the end of trial the body mass was controlled, as well as the incidence of foot-pad and hock burns and their severity were evaluated and quality of litter analysed. Research results indicate significant effect of the diets from the aspect of broiler welfare and productivity. Application of the feeding program declared in the nutritional/economical sense as economical resulted in higher content of litter moisture, significantly higher frequency of incidence of the most severe forms of foot-pad dermatitis and significantly lower broiler performance.

Key words: broilers, diets, foot-pad dermatitis, productivity

\section{Introduction}

Foot-pad dermatitis is important indicator in broiler welfare assessment (Škrbić et al., 2011) but recently it became important also from the market aspect, considering that chicken legs represent valuable product on the Asian market. Footpad dermatitis represents form of contact dermatitis associated with moist litter (Sorensen et al., 2000; Dozier et al., 2005). Control of the quality and moisture content in the litter is the priority of the modern intensive poultry production which prevents problems associated with the environment conditions, poultry welfare and 
reduces the production losses. Litter quality depends on the choice of litter material, its fragmentation, thermo-isolation properties of the facility, ventilation, stocking density and nutrition. The effects of nutrition on litter quality are expressed through energy/protein ratio, content of crude proteins, amino acid balance, fat content and type, electrolytic balance in mixtures, form of mixtures (floury-pelleted), nutrition regime (ad libitum-restrictive). The use of barley, rye or wheat in mixtures for broilers reduces the digestibility and increases the viscosity of digesta which is main cause of increased water consumption and water content in faeces (Francesch and Brufau, 2004). In addition, as a consequence of actual ban of animal proteins, the high level of plant proteins in the composition of poultry mixtures implicates increase of the quantity carbon-hydrates as well, which results in bad digestibility, absorption and in increase of incidence of nonspecific digestion disorders that influence water consumption and litter quality. Restrictive nutrition by only $10 \%$ of ad libitum significantly increases the moisture of the litter (Huang et al., 2011).Significant differences in the quality of broiler paw fed mixtures of various producers, without any deficits or imbalances between nutrients in mixtures, have been established by Ekstrand et al. (1998).

Trend of increase of maize and soybean prices in the world and domestic markets, with evaluation that the prices of these two main energy/protein food components of the highest quality used in poultry nutrition will maintain this level long-term (Ziggers, 2011), further aggravate formulation of high value nutritional mixture programs used in feeding of modern broilers at an acceptable market price. Consequently, quality of complete forage mixtures which can be purchased commercially varies in spite of similar prices and respecting of regulated basic chemical composition, primarily in regard to nutritional value of food which is demonstrated on the farm, i.e. through animal productivity. Cause is most often the application of cheap raw materials of lower quality as well as lack of good quality additives in mixture formulations (Lukić et al., 2009).

Objective of the paper was to investigate the effect of the diets from two, commercially available broiler feeding programs, declared in nutritional/economical sense as standard and economical, on production performance, litter quality and incidence of leg dermatitis (foot-pad and hock burns).

\section{Materials and Methods}

Total of 500 one day old broiler chickens of Hubbard genotype were divided into 2 groups. Chickens of each group were distributed in 5 boxes (replicates). Standard technology of broiler fattening in the floor system was applied, with stocking density of $13 \mathrm{bird} / \mathrm{m}^{2}$, nutrition ad libitum and duration of fattening of 42 days. Chopped straw was used as litter. Broiler groups were fed 3 
mixtures (starter, grower and finisher were used to day 21, 35 and 42 of fattening, respectively) from a commercially available feeding programs produced in the same facility for production of animal food. Complete forage mixtures from the standard feeding program were used in nutrition of broilers of the first group (D1), whereas the complete mixtures from the "economic" feeding program of the same producer were used in nutrition of chickens of the second group (D2). All mixtures were in the floury form in order to enable their comparison. Chemical composition and microbiological quality were tested using accredited methods in the laboratory of the Institute for Animal Husbandry, Belgrade-Zemun.

During the trial duration, mortality and food consumption were recorded per box, so in the statistical data processing the box represented observation unit. Control of body mass was carried out by individual weighing of all trial chickens, at the age of 42 days. At the same time, on a random sample of 52 broilers per treatment (total of 104 broilers), with equal share of male and female broilers, the incidence and severity of forms of foot-pad lesions were evaluated according to method by Thomas et al. (2004). Foot pad lesions were scored using the three point scale: score $1=$ no lesions; score $2=$ mild lesions; score $3=$ severe lesions. According to the same method hock burns were also scored.

For the purpose of estimation of litter quality, at the end of trial, from 5 locations for measuring in each box, litter sample was taken to determine the moisture content, by method of sample drying at $105^{\circ} \mathrm{C}$ to constant mass.

Data was analysed using the method of variance analysis and Tukey test (Stat.Soft,Inc. STATISTICA, version 6). Statistical analysis of the frequency of assessments in case of foot-pad dermatitis and hock burns in trial groups was done after transformation of data (arcsin transformation), and for the purpose of clearer perceiving in tables they are presented in percentages.

Production index was calculated according to formula:

Body mass (kg) x vitality (\%) x 100

Duration of fattening (days) $\mathrm{x}$ feed conversion $(\mathrm{kg})$

\section{Results and Discussion}

Established chemical composition of mixtures used in the trial is presented in Table 1. 
Table 1. Chemical composition of mixtures in investigated nutrition programs

\begin{tabular}{|c|c|c|c|c|c|c|}
\hline \multirow{2}{*}{$\begin{array}{l}\text { Investigated } \\
\text { parameter }\end{array}$} & \multicolumn{2}{|c|}{ Starter } & \multicolumn{2}{|c|}{ Grower } & \multicolumn{2}{|c|}{ Finisher } \\
\hline & D1 & D2 & D1 & D2 & D1 & D2 \\
\hline $\begin{array}{l}\text { Crude } \\
\text { protein, } \%\end{array}$ & 21.44 & 21.43 & 18.57 & 18.87 & 16.43 & 17.10 \\
\hline Moisture, $\%$ & 10.89 & 10.18 & 11.28 & 11.10 & 11.34 & 10.49 \\
\hline Crude fat, $\%$ & 7.19 & 5.99 & 6.55 & 5.42 & 5.19 & 4.46 \\
\hline Crude fibre, $\%$ & 5.92 & 6.31 & 5.55 & 6.06 & 6.41 & 5.65 \\
\hline Ashes, $\%$ & 6.19 & 6.79 & 6.25 & 5.07 & 4.85 & 5.30 \\
\hline Calcium,\% & 1.08 & 1.20 & 0.93 & 0.91 & 0.80 & 0.90 \\
\hline $\begin{array}{l}\text { Total } \\
\text { phosphorus, } \%\end{array}$ & 0.76 & 0.69 & 0.74 & 0.67 & 0.67 & 0.76 \\
\hline Sodium, $\%$ & 0.20 & 0.17 & 0.19 & 0.16 & 0.14 & 0.16 \\
\hline
\end{tabular}

Basic chemical composition of mixtures, presented in Table 1, corresponded to required minimum parameters of quality stipulated by the current national rulebooks for this type of complete mixtures used in fattening broilers. From presented results it can be observed that same mixtures from two different feeding programs varied only slightly in regard to the chemical composition. Starter and grower mixtures in D1 group had by approx. 1\% more fat, by half percentage less fibre and insignificantly more total phosphorus compared to adequate mixtures from D2 group. This indicates differences in raw material composition and/or percentage of raw materials used in formulating of the mixtures from these two programs, for the purpose of obtaining the price difference.

Application of investigated diets resulted in differences in the litter quality, i.e. moisture content, which in group D1 was $56.8 \%$ and in group D2 $62.4 \%$ ( $>0.05$ ). The main reason for higher moisture content and lower litter quality in group D2, and based on differences established between mixtures which indicated slightly lower digestibility and nutritional value of mixtures from D2 program, their impact on the digesta viscosity can be implied, causing the reduced water absorption and increased water loss through excretions. The impact on the digesta viscosity is main cause for water consumption and moisture content in faeces of poultry fed barley, rye, wheat and triticale (Francesch and Brufau, 2004). Also, slightly lower energy level of D2 diets potentially could have influenced water consumption, which increases in that case (Huang et al., 2011) and consequently results in higher moisture content of litter. 
Table 2. Average score and frequency (\%) of incidence of foot-pad lesions scored from 1 to 3

\begin{tabular}{|c|c|c|c|c|c|}
\hline \multirow{2}{*}{\multicolumn{2}{|c|}{ Treatment }} & \multicolumn{3}{|c|}{ Frequency of score, $\%$} & \multirow{3}{*}{$\begin{array}{c}\text { Average score } \\
1.82 \\
\end{array}$} \\
\hline & & \multirow{2}{*}{$\begin{array}{c}1 \\
27.3\end{array}$} & \multirow{2}{*}{$\begin{array}{c}2 \\
63.6\end{array}$} & \multirow{2}{*}{$\begin{array}{c}3 \\
9.1\end{array}$} & \\
\hline \multirow{3}{*}{ D1 } & 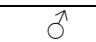 & & & & \\
\hline & q & 44.4 & 44.4 & 11.2 & 1.67 \\
\hline & $\hat{0}+q$ & 35.2 & 54.7 & 10.1 & 1,75 \\
\hline \multirow{3}{*}{ D2 } & $\hat{\sigma}^{+}$ & 22.2 & 44.4 & 33.3 & 2.11 \\
\hline & ㅇ & 18.2 & 45.4 & 36.4 & 2.18 \\
\hline & $\hat{\sigma}+q$ & 20.1 & 44.8 & 35.1 & 2.15 \\
\hline \multicolumn{2}{|c|}{ Diet } & NS & NS & ** & \\
\hline
\end{tabular}

Frequency of incidence of the most severe forms of foot-pad dermatitis was significantly $(p<0.01)$ higher in group D2 (table 2$)$, which is in concordance with established moisture content in litter which is mainly responsible for incidence of contact dermatitis. According to Meluzzi et al. (2008), correlation coefficient between the moisture content of litter and foot-pad dermatitis is 0.87 . Accordingly, in D1 group higher frequency of broilers without lesions and with incidence of mild lesions was registered. Contrary to foot-pad dermatitis, no significant differences were established in frequency of incidence of chicken hock burns were established in studied treatments (table 3). Obtained results can be associated with body masses of broiler which were significantly higher in D1 group (table 4) and which affect the physical (in)activity of broilers (Eukić Stojcić and Bessei, 2011) and time period during which the hock was exposed to the contact with litter. Broilers spend during one day $76-86 \%$ of total time lying down. With the increase of body mass this percentage approaches the top limit (Weeks et al., 2000).

In addition to body mass, broilers in group D1 realized significantly higher production index based on generally better production performances of these broilers. Production results confirmed the significance of the quality of raw materials and/or use of additives in formulation of mixtures (Lukić et al., 2009) which influences the digestibility and at the same time the nutritional value. In that sense, biological trials represent the only reliable way to establish the quality of mixtures.

Results of the trial confirm the hypothesis regarding the compromised welfare of broilers fed mixtures from D2 diets based on significantly higher incidence of the most severe forms of foot-pad dermatitis in broilers from that group, which reduced their mobility because of the pain that they experienced and in this way influenced the decrease of body mass. Hence, the body mass can be considered as welfare indicator (Škrbić et al., 2011). In concordance with statements of Ekstrand et al. (1998), variability of the mixture quality between producers which are available commercially reflects on moisture content of litter or 
integrity of skin through vitamin insufficiency, such as biotin and in this way initiate difference sin dermatitis incidence.

Table 3. Average score and frequency of incidence (\%) of hock burns scored from 1 to 3

\begin{tabular}{|c|c|c|c|c|c|}
\hline \multirow{2}{*}{\multicolumn{2}{|c|}{ Treatment }} & \multicolumn{3}{|c|}{ Frequency of score, $\%$} & \multirow{2}{*}{ Average score } \\
\hline & & 1 & 2 & 3 & \\
\hline \multirow{3}{*}{ D1 } & $\pi$ & 63.6 & 27.3 & 9.1 & 1.42 \\
\hline & 웅 & 100 & 0 & 0 & 1.00 \\
\hline & $\hat{o}+q$ & 82.7 & 13.5 & 3.8 & 1.21 \\
\hline \multirow{3}{*}{ D2 } & $\delta^{1}$ & 77.8 & 22.2 & 0 & 1.23 \\
\hline & q & 100 & 0 & 0 & 1.00 \\
\hline & $\hat{0}+q$ & 88.5 & 11.5 & 0 & 1.11 \\
\hline \multicolumn{2}{|c|}{ Diet } & NS & NS & NS & \\
\hline
\end{tabular}

Table 4. Broilers' production traits in investigated feeding programs

\begin{tabular}{|c|c|c|c|c|c|}
\hline \multicolumn{2}{|c|}{ Treatment } & Body mass 42.day, $\mathrm{g}$ & Mortality, & $\begin{array}{l}\text { Feed } \\
\text { conversion, }\end{array}$ & P.I. \\
\hline \multirow[t]{2}{*}{ D1 } & $\begin{array}{l}1 \\
0 \\
9\end{array}$ & $\begin{array}{c}2154.87 \pm 360.25 \\
2056.66 \pm 303.89\end{array}$ & \multirow[t]{2}{*}{3.6} & \multirow[t]{2}{*}{1.96} & \multirow[t]{2}{*}{$246.4^{\mathrm{A}}$} \\
\hline & $\hat{0}+0$ & $2104.65 \pm 335.92^{\mathrm{A}}$ & & & \\
\hline \multirow[t]{2}{*}{ D2 } & $\begin{array}{l}\hat{0} \\
0 \\
+\end{array}$ & $\begin{array}{l}1901.67 \pm 296.78 \\
1895.56 \pm 285.49\end{array}$ & \multirow[t]{2}{*}{4.0} & \multirow[t]{2}{*}{2.08} & \multirow[t]{2}{*}{$208.8^{\mathrm{B}}$} \\
\hline & $\pi+q$ & $1898.46 \pm 290.32^{\mathrm{B}}$ & & & \\
\hline \multicolumn{6}{|c|}{ Significance } \\
\hline \multicolumn{2}{|c|}{ Diet } & $\mathrm{p}<0.01$ & NS & $\mathrm{p}=0.05$ & $\mathrm{p}<0.01$ \\
\hline
\end{tabular}

Values are presented as $\bar{x} \pm \mathrm{Sd}$

* A-B Average values in each column without common indications are significantly different at the level of $1 \%, \mathrm{p}<0.01$

\section{Conclusion}

Research results confirmed the differences in the quality, primarily nutritional, between complete mixtures for fattening of broilers from two feeding programs in spite of very slight differences in chemical composition.

Application of diets from feeding program declared in the nutritional/economical sense as economical, resulted in higher moisture content in litter, significantly higher frequency of incidence of the most severe forms of footpad dermatitis and significantly lower production performances of broilers. Based on this, negative effect was demonstrated on welfare and productivity of broilers. Economical profitability of application of such feeding programs in broiler fattening should be topic of future additional studies. 


\title{
Acknowledgment
}

Research was part of the project TR 31033, financed by the Ministry of Education and Science of the Republic of Serbia.

\section{Efekat programa ishrane na pojavu lezija na nogama $i$ produktivnost brojlera}

\author{
Z. Škrbić, Z. Pavlovski, M. Lukić, V. Petričević, B. Miljković, G. Marinkov
}

\section{Rezime}

Ishranbeni faktori se smatraju veoma značajnim za nastanak dermatitisa na nožnim jastučićima brojlera preko uticaja na kvalitet prostirke. Cilj rada je bio ispitivanje efekta upotrebe dva, tržišno dostupna programa ishrane brojlera koji su deklarisani u nutritivno/ekonomskom smislu kao standardan i ekonomičan, na kvalitet prostirke, pojavu dermatitisa na nogama i proizvodne performanse. Ogled je izveden na 500 jednodnevnih pilića genotipa Hubbard, sa dva tretmana i pet ponavljanja. Za prostirku je korišćena seckana slama. Tokom ogleda su evidentirani mortalitet i utrošak hrane a na kraju ogleda je izvršena kontrola telesne mase, ocena pojave i težine oblika lezija na nožnim jastučićima i skočnim zglobovima, analiza kvaliteta prostirke.

Rezultati istraživanja su ukazali na značajan efekat programa ishrane sa stanovišta dobrobiti i produktivnosti brojlera. Primena programa ishrane deklarisanog u nutritivno/ekonomskom smislu kao ekonomičnog, rezultirala je većim sadržajem vlage u prostirci, značajno većom frekvencijom pojavljivanja najtežih oblika dermatitisa na nožnim jastučićima i značajno lošijim performansama brojlera.

\section{References}

DOZIER W.A., THAXTON J.P., BRANTON S.L., MORGAN G.W., MILES D.M., ROUSH W.B., LOTT B.D., VIZZIER-THAXTON Y. (2005): Stocking Density on Growth Performance and Processing Yields of Heavy Broilers. Poultry Science, 84,1332-1338.

DJUKIĆ STOJČIĆ M. and BESSEI W. (2011): The effect of weight load on the legs of broilers behavior. Biotechnology in Animal Husbandry, 27, 4, 1667-1671. 
EKSTRAND C., CARPENTER T.E., ANDERSON I., ALGERS B. (1998): Prevalence and control of foot-pad dermatitis in broilers in Sweden. British Poultry Science, 39, 318-324.

FRANCESCH M. and BRUFAU J. (2004): Nutritional factors affecting excreta/litter moisture and quality. World's poultry Science Journal, 60, 64-75.

HUANG K.H., KEMP C., FISHER C. (2011): Effects of nutrition on water intake and litter moisture on broiler chickens. Proceedings of $22^{\text {nd }}$ Annual Australian Poultry Science Symposium, Sidney, February 2011, 26-32.

LUKIĆ M., PAVLOVSKI Z., ŠKRBIĆ Z. (2009): Savremeni aspekti ishrane živine. 18. Savetovanje živinara, Živinarstvo, 44, 9, 15-26.

MELUZZI A., FABBRI C., FOLEGATTI E., SIRRI F. (2008): Survey of chicken rearing conditions in Italy: effects of litter quality and stocking density on productivity, foot dermatitis and carcase injuries. British Poultry Science 49, 257-264. SORENSEN P., SU G., KESTIN S.C. (2000): Effects of Age and Stocking Density on Leg Weakness in Broiler Chickens. Poultry Science, 79, 864-870.

ŠKRBIĆ Z., PAVLOVSKI Z., LUKIĆ M., PETRIČEVIĆ V., ĐUKIĆ STOJČIĆ M., ŽIKIĆ D. (2011): The effects of stocking density on individual broiler welfare parameters 2. Different broiler stocking densities. Biotechnology in Animal Husbandry, 27, 1, 17-25.

THOMAS D.G., RAVINDRAN V., THOMAS D.V., CAMDEN B.J., COTTAM Y.H., MOREL P.C.H., COOK C.J. (2004): Influence of stocking density on the performance, carcass characteristics and selected welfare indicators of broiler chickens. New Zealand Veterinary Journal, 52, 76-81.

WEEKS C.A., DANBURY T.D., DAVIES H.C., HUNT P., KESTIN S.C. (2000): The behaviour of broiler chickens and its modification by lameness. Applied Animal Behaviour Science, 67, 111-125.

ZIGGERS D. (2011): Optimising nutrient density in a volatile market. All About Feed, 2,3, 18-20. 